\title{
Quantitative examination of macrobenthic community changes along an organic enrichment gradient
}

\author{
Donald P. Weston* \\ School of Oceanography, WB-10, University of Washington, Seattle, Washington 98195, USA
}

\begin{abstract}
Organic enrichment, both natural and anthropogenic, is one of the most common forms of disturbance in the benthos. The effects of organic enrichment on the benthos in the vicinity of a large mariculture facility were examined as a general model for enrichment, without the confounding effects of toxicants often associated with anthropogenic inputs. Stations nearest the facility were subject to continuous input of fish feed and fecal matter, and gross structural changes in the macrofaunal community (e.g. reduced species richness, dominance of opportunistic species) were similar to those commonly reported for other enriched sites. More complex community and population responses were indicated by changes in body size, vertical distribution of infauna and patterns of trophic dominance. Enriched areas are generally assumed to be characterized by macrofauna with small body sizes, and mean individual size did, in fact, decrease with proximity to the farm. At stations farthest from the farm. however, size distributions were skewed by a few large individuals, indicating that trends in mean individual size are susceptible to the methodological limitations inherent in adequately sampling rare individuals. While interspecific measures of animal size decreased with increasing enrichment, intraspecific measures indicated a tendency for larger individuals to occur at the most enriched sites. Enriched areas may represent increased food resources, and thus increased potential for growth and attainment of larger body sizes in those species capable of exploiting such habitats. Organically enriched areas are generally considered to be characterized by infauna living at or near the sedimentwater interface. Increasing organic enrichment resulted in the loss of large, deep-dwelling species and dramatically altered the vertical biomass profiles, but, because these individuals were numerically few, had little effect on the vertical abundance profiles. Changes in trophic dominance did occur along the enrichment gradient, but the general lack of autecological information limits current efforts to define trophic groups and assign species to them. The utility of trophic grouping approaches in identification of enrichment-induced disturbances is thus limited.
\end{abstract}

\section{INTRODUCTION}

Organic enrichment is one of the most common disturbances of marine macrobenthic communities. Much research has concentrated on the effects of organic enrichment from anthropogenic sources (e.g. sewage discharge), but the effects of natural enrichment are comparable (Simon \& Dauer 1977, Thiel 1978). Consistent correlations between organic enrichment and gross measures of community structure, such as species richness, dominance and total animal abundance, have

\footnotetext{
- Present address: University of Maryland, Horn Point Environmental Laboratories, PO Box 775, Cambridge, Maryland 21613, USA
}

been reported for many geographic locations and types of organic material. These observations are the basis for empirical models that describe the impacts on marine macrofauna of disturbance, in general, and organic enrichment, in particular (Pearson \& Rosenberg 1978, Gray 1979, Rhoads \& Boyer 1982). It is generally assumed that a macrobenthic community subject to increased organic loading, either spatially or temporally, will exhibit: (1) a decrease in species richness and an increase in total number of individuals as a result of the high densities of a few opportunistic species; (2) a general reduction in biomass, although there may be an increase in biomass corresponding to a dense assemblage of opportunists; (3) a decrease in body size of the average species or individual; (4) a 
shallowing of that portion of the sediment column occupied by infauna; (5) shifts in the relative dominance of trophic guilds. Pearson \& Rosenberg (1978) predict dominance of subsurface deposit feeders in enriched areas, while Rhoads \& Boyer (1982) predict dominance of species feeding at, or near $(<2 \mathrm{~cm})$, the sediment-water interface.

Some of these enrichment effects, such as a decrease in species richness and a dominance of opportunistic species, have been documented many times. Other effects, such as shallowing of vertical distributions, have been observed qualitatively but never quantified.

In this investigation I reexamine population and community-level responses of benthic macroinvertebrates subject to organic enrichment. The study was designed, in part, to assess quantitatively those aspects of existing empirical organic enrichment models that have been accepted with little or no supportive data. The study site was near a commercial salmon farm, and the deposition of waste feed and feces provided a classic example of organic enrichment with few, if any, associated toxicants.

\section{MATERIALS AND METHODS}

The salmon farm, located in Puget Sound, Washington, USA, is large by carrent industry standards. It consists of 160 net-cages covering a total surface area of $1.7 \mathrm{ha}$, and produces about 620 metric tons of fish annually. A farm of this size generates 250 t organic carbon annually in fecal material and waste feed (Gowen \& Bradbury 1987). The farm has been operating for about $15 \mathrm{yr}$. Water depth in the sampling area ranges from 13 to $20 \mathrm{~m}$ (MLLW). Salinity and temperature of near-bottom water were $29.4 \mathrm{ppt}$ and $11^{\circ} \mathrm{C}$, respectively, at the time of sampling. Current velocity measured $6 \mathrm{~m}$ above the seafloor averaged $6 \mathrm{~cm} \mathrm{~s}^{-1}$ (mean of 689 observations) with a maximum of $31 \mathrm{~cm}$ $\mathrm{s}^{-1}$. Tidal currents alternately flow to the northwest and south, with a net current direction to the west.

In June 1987, 5 stations were sampled along a transect extending from the farm perimeter to a distance of $450 \mathrm{~m}$ (Fig. 1). Sampling stations were located to avoid a small aquaculture research facility northwest of the commercial farm. The research facility has an annual fish production about $1 \%$ of the production of the commercial farm $(7 \mathrm{t})$, and qualitative observations indicated that benthic effects were limited to within a few meters of the facility.

At each station 3 samples were collected using a $0.06 \mathrm{~m}^{2}$ spade corer (depth of penetration generally $20 \mathrm{~cm}$ ). Subsamples were removed from each core for physical and chemical analyses, and the cores were then sectioned into 5 vertical strata $(0-1,1-2,2-5$, 5-10 and $10-20 \mathrm{~cm}$ ). For 2 cores from each station, strata above $5 \mathrm{~cm}$ were sieved on a $0.5 \mathrm{~mm}$ screen and the deeper strata were sieved on a $1.0 \mathrm{~mm}$ mesh on the assumption that macrofauna burrowing below 5 $\mathrm{cm}$ would tend to be relatively large. This assumption was tested by processing the deeper strata from one

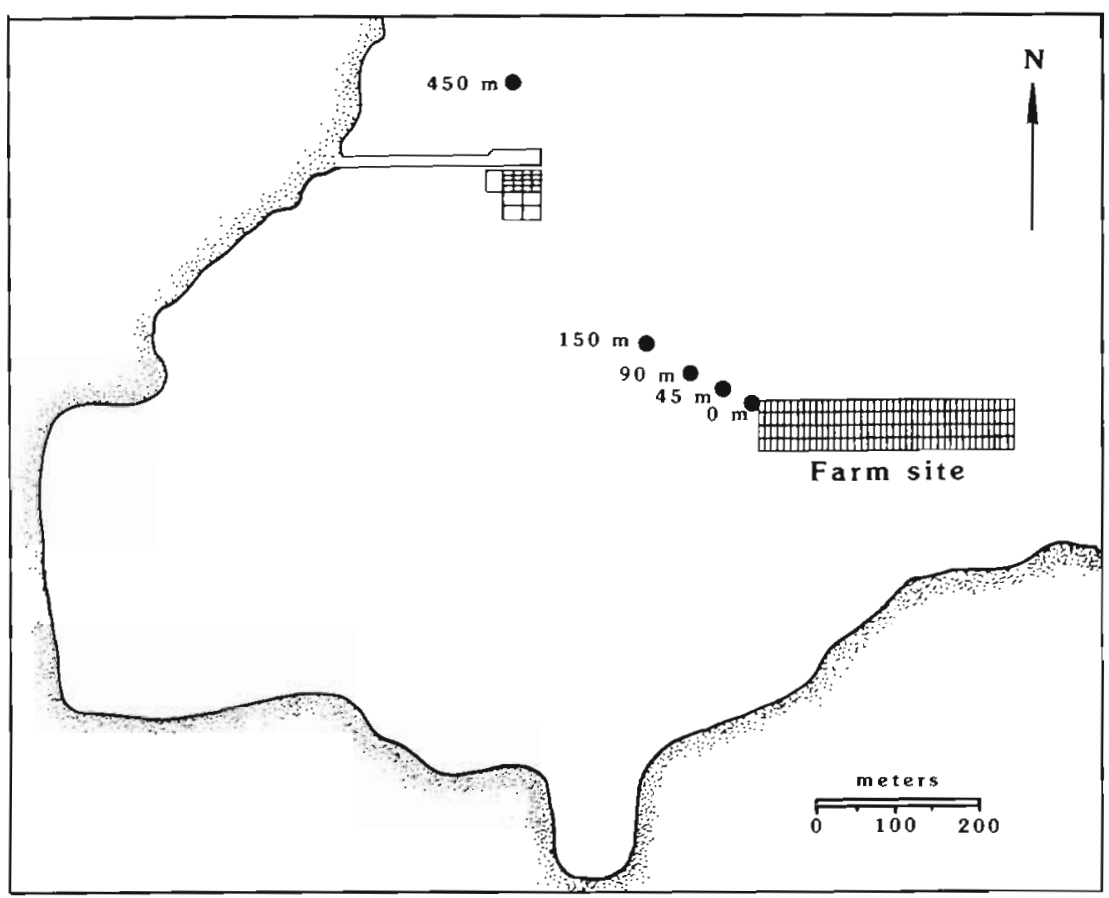

Fig. 1 Location of the 5 stations along a transect from the commercial farm (middle right). A small fisheries research facility is also indicated (middle top). Seattle, Washington is $14 \mathrm{~km}$ to the east 
core from each station with stacked 0.5 and $1.0 \mathrm{~mm}$ sieves. The $1.0 \mathrm{~mm}$ sieve alone retained an average of $50 \%$ of the individuals and over $99 \%$ of the biomass that would be retained had only a $0.5 \mathrm{~mm}$ sieve been used. Abundances in the deeper strata thus are underestimated by about a factor of 2 while biomass profiles are little affected. These biases do not significantly affect interpretations.

Animals were fixed in formalin and later transferred to $70 \%$ ethanol. Biomass of each species was measured as wet weight after blotting with absorbent paper. All individuals of a species in a given depth stratum in a given core were grouped for biomass measurement. Animals were removed from tubes prior to biomass determination, but mollusc and echinoderm biomass includes the weight of calcified structures.

Sediment samples from the upper $2 \mathrm{~cm}$ of the sediment column were used in the chemical analyses. CHN analyses were done using a Carlo Erba microanalyzer following vapor-phase acidification (Hedges \& Stern 1984). Water-soluble sulfide samples were field-preserved with $2 \mathrm{~N}$ zinc acetate and held at $4^{\circ} \mathrm{C}$. At the time of analysis an anti-oxidant buffer was added and sulfide concentrations were determined by potentiometric titration (Green \& Schnitker 1974). Since 2 to 3 wk elapsed between collection and analysis, the sulfide data are only useful for relative rather than absolute comparisons among samples. Grain-size distributions ( 0 to $5 \mathrm{~cm}$ stratum) were determined by dry sieving and pipette analysis of the silt and clay fractions. Sediment redox measurements (Pearson \& Stanley 1979) were made during an independent survey in August 1988

Numerical classification with log-transformation of species abundances and squared Euclidean distance as a measure of similarity was used to group stations on the basis of faunal similarities. Two sorting strategies, Ward's method and the unweighted pair-group method using arithmetic averages, were tested with similar results. Species collected in only one sample were excluded (77 species); 119 species were used in analyses.

\section{RESULTS}

\section{Physical and chemical data}

Grain size was similar throughout the transect (Table 1) and, excluding the $0 \mathrm{~m}$ station, averaged $97 \%$ sand, $1 \%$ silt and $2 \%$ clay At the farm perimeter $10 \mathrm{~m}$ station), the visible accumulation of feed and feces resulted in a slightly greater proportion of fine sediment ( $8 \%$ silt and clay) with a greater water content. Sedimentation rates of 13.3 and $3.6 \mathrm{~kg} \mathrm{C} \mathrm{m}^{-2} \mathrm{yr}^{-1}$ were measured by sediment traps directly under the center of the farm and at the $0 \mathrm{~m}$ station, respectively, in July 1988 (Weston \& Gowen unpubl.).

All chemical measurements indicated that the $0 \mathrm{~m}$ station was heavily affected by culture activities. The organic carbon content of the sediment was about 4 times that at most other stations. Nitrogen and water-soluble sulfide concentrations were also substantially elevated, and the sediment redox potential was depressed. Similar effects were apparent $45 \mathrm{~m}$ from the farm, although there was considerable variability in degree of enrichment among the 3 cores at that station. Based on sediment chemistry alone, no indications of organic enrichment were apparent at distances of $90 \mathrm{~m}$ or greater.

The effects of culture activities on the seafloor were readily visible. Beneath and within a few meters of the farm, depressions on the bottom were filled with fish fecal material and uningested feed pellets. Sulfuroxidizing bacteria Beggiatoa spp. formed dense white mats on the sediment surface at distances of 30 to $80 \mathrm{~m}$ from the farm. The mats were present but not as well developed under the pens and at distances from 80 to at least $150 \mathrm{~m}$ from the farm. No Beggiatoa mats were apparent at the $450 \mathrm{~m}$ station

Table 1. Physical and chemical measurements (mean and range; $n=3$ except $E_{h}$ ) from surficial sediments at the 5 stations along a transect from the fish culture site

\begin{tabular}{|c|c|c|c|c|c|c|}
\hline $\begin{array}{l}\text { Distance } \\
(\mathrm{m})\end{array}$ & $\begin{array}{c}\text { Silt and clay } \\
(\%)\end{array}$ & $\begin{array}{l}\text { Water content } \\
(\%)\end{array}$ & $\begin{array}{c}\text { Organic carbon } \\
(\%)\end{array}$ & $\begin{array}{l}\text { Total nitrogen } \\
\qquad(\%)\end{array}$ & $\begin{array}{l}\text { Water-soluble sulfide } \\
\left(\mathrm{mg} \mathrm{kg}^{-1} \text { dry } w \mathrm{t}\right)\end{array}$ & $\begin{array}{c}E_{\mathrm{h}} \text { at } 4 \mathrm{~cm} \text { depth } \\
(\mathrm{mV})\end{array}$ \\
\hline 0 & $\begin{array}{c}8.0 \\
(6.7-9.4)\end{array}$ & $\begin{array}{c}30.2 \\
(28.1-32.7)\end{array}$ & $\begin{array}{c}1.26 \\
(0.89-1.60)\end{array}$ & $\begin{array}{c}0.16 \\
(0.11-0.21)\end{array}$ & $\begin{array}{c}28.5 \\
(21.1-34.0)\end{array}$ & 120 \\
\hline 45 & $\begin{array}{c}2.5 \\
(2.3-2.6)\end{array}$ & $\begin{array}{c}21.1 \\
(20.3-21.9)\end{array}$ & $\begin{array}{c}0.41 \\
(0.15-0.76)\end{array}$ & $\begin{array}{c}0.07 \\
(0.02-0.13)\end{array}$ & $\begin{array}{c}15.1 \\
(10.8-23.2)\end{array}$ & 150 \\
\hline 90 & $\begin{array}{c}2.9 \\
(2.6-3.1)\end{array}$ & $\begin{array}{c}22.3 \\
(21.7-22.8)\end{array}$ & $\begin{array}{c}0.29 \\
(0.28-0.30)\end{array}$ & $\begin{array}{c}0.04 \\
(0.03-0.04)\end{array}$ & $\begin{array}{c}8.6 \\
(5.3-11.4)\end{array}$ & 295 \\
\hline 150 & $\begin{array}{c}3.1 \\
(2.8-3.3)\end{array}$ & $\begin{array}{c}22.7 \\
(22.4-23.3)\end{array}$ & $\begin{array}{c}0.20 \\
(0.18-0.23)\end{array}$ & $\begin{array}{c}0.03 \\
(0.02-0.03)\end{array}$ & $\begin{array}{l}10.4 \\
(9.1-12.3)\end{array}$ & 350 \\
\hline 450 & $\begin{array}{c}3.8 \\
(2.0-5.3)\end{array}$ & $\begin{array}{c}20.7 \\
(14.6-24.7)\end{array}$ & $\begin{array}{c}0.35 \\
(0.30-0.40)\end{array}$ & $\begin{array}{c}0.04 \\
(0.04-0.04)\end{array}$ & $\begin{array}{c}5.1 \\
(2.5-11.1)\end{array}$ & \\
\hline
\end{tabular}




\section{Classification of faunal assemblages}

Four groups were identified in numerical classification of the 15 samples ( 3 at each of the 5 stations). Group 1 , the 3 samples from the $450 \mathrm{~m}$ station, was the least similar to the other groups. Group 2 consisted of the 3 samples from the $150 \mathrm{~m}$ station and 1 sample from the $90 \mathrm{~m}$ station. The 2 remaining samples from the $90 \mathrm{~m}$ station and the samples from the $45 \mathrm{~m}$ station comprised Group 3. Group 4 consisted exclusively of those samples from the $0 \mathrm{~m}$ site. These results indicate that the 5 stations differed by more than distance from the farm they represented different faunal assemblages. It is thus reasonable to compare and contrast these 5 stations to evaluate the effects of organic enrichment.

\section{Species richness, abundance and biomass}

The $450 \mathrm{~m}$ station was characterized by a speciesrich assemblage with an average of 109 macrobenthic species per sample (Fig. 2). The capitellid polychaete Mediomastus californiensis, oligochaetes and the ostracod Euphilomedes carcharodonta were numerically dominant (Table 2). Dense tube mats of Spiochaetopterus oculatus were present, the number of terebellid polychaete species was high (13 species), and large sipunculans (Golfingia pugettensis) and echiurans (Arhynchite pugettensis) were conspicuous members of the community. With increasing proximity to the farm site, and presumably a concomittant increase in the rate of organic loading, species richness decreased more or less linearly. Samples from the $0 \mathrm{~m}$ station yielded an average of only 9 macrofaunal species. Nematodes and Capitella cf. capitata

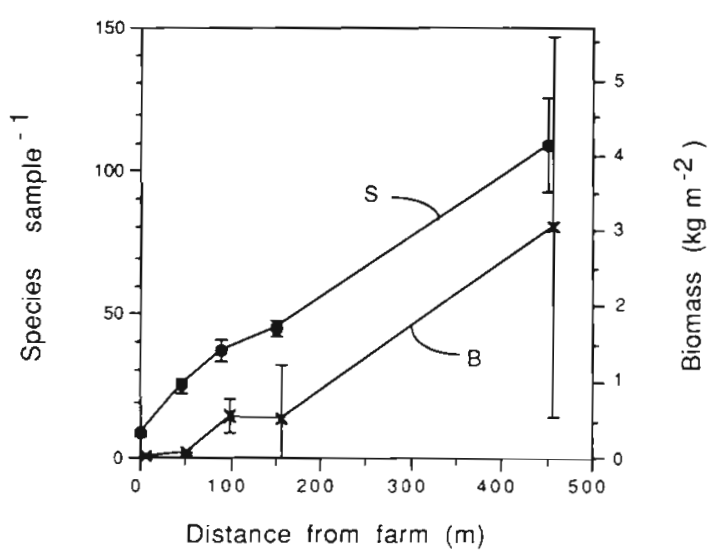

Fig. 2. Mean and standard deviation of areal species richness (S) and total cormmunity biomass (B) along the sampling transect. Values on the abscissa for the 2 curves have been slightly offet to avoid overlapping error bars accounted for over $99 \%$ of the total number of individuals at the $0 \mathrm{~m}$ station.

The total number of individuals (Fig. 3) dramatically increased at the station nearest the farm site when nematodes were included. Excluding nematodes from the analysis, macrofaunal density declined as organic enrichment increased. Densities of 'opportunistic' species, most notably Capitella cf. capitata, increased by an order of magnitude along the transect from $450 \mathrm{~m}$ to the farm (Table 2), but this increased density of C. capitata with proximity to the farm was offset by decreases in abundances of other species.

Total community biomass (Fig. 2) decreased more or less linearly with increased proximity to the farm site. Since the nematodes were small compared to the macrofauna, their high densities near the farm contributed little to total biomass. Nematodes typically fall into meiofaunal size classes and thus have been excluded from all further analyses. They were not sampled quantitatively - only the largest individuals were retained on the $0.5 \mathrm{~mm}$ mesh.

\section{Animal size}

Areas subject to organic enrichment are generally characterized by smaller animals (Pearson \& Rosenberg 1978). The hypothesis that body size decreased with increasing proximity to the farm site was tested using several parameters. The first parameter, mean individual size (i.e. total sample biomass/total number of individuals in the sample), decreased from $98 \mathrm{mg}$ at $450 \mathrm{~m}$ from the farm to $3 \mathrm{mg}$ at the farm perimeter, and was directly correlated with distance from the culture site (Spearman rank correlation, 1-tailed test, $\mathrm{p}<0.01$ ).

A second parameter, mean species size was also calculated:

$$
\frac{\sum_{i=1}^{n} \frac{B_{1}}{A_{i}}}{n}
$$

where $B_{1}$ and $A_{i}=$ the biomass and abundance of species $i$, respectively; and $n=$ number of species in the sample. This second parameter also showed a significant decrease at the stations nearest the farm (Spearman rank correlation, 1-tailed test, $\mathrm{p}<0.01$ ). Mean species size was about $500 \mathrm{mg}$ at distances of $90 \mathrm{~m}$ or more from the farm site, $48 \mathrm{mg}$ at a distance of $45 \mathrm{~m}$, and $2 \mathrm{mg}$ at the farm perimeter

Much information is lost, however, in calculating a mean individual or mean species size, and the data can be better presented in terms of size distributions. Body size (i.e. weight) classes were calculated on a $\times 2$ geometric scale (Warwick 1984), and size class fre- 
Table 2. Species accounting for $>1 \%$ of total individuals at any of the sampling stations and their density along the transect (ind. $\mathrm{m}^{-2}$; mean of 3 samples)

\begin{tabular}{|c|c|c|c|c|c|}
\hline \multirow[t]{2}{*}{ Species } & \multicolumn{5}{|c|}{ Distance from farm (m) } \\
\hline & 0 & 45 & 90 & 150 & 450 \\
\hline Nematoda & 90507 & 8600 & 1080 & 320 & 3360 \\
\hline Rhyncocoela & 0 & 40 & 67 & 87 & 320 \\
\hline \multicolumn{6}{|l|}{ Polychaeta } \\
\hline Armandia brevis & 0 & 947 & 873 & 267 & 93 \\
\hline Barantolla americana & 0 & 80 & 73 & 180 & 147 \\
\hline Capitella cf. capitata & 8340 & 6020 & 5740 & 5080 & 960 \\
\hline Cirratulus cirratus & 0 & 0 & 0 & 0 & 513 \\
\hline Euclymene zonalis & 0 & 0 & 0 & 0 & 1020 \\
\hline Glycinde picta & 73 & 433 & 587 & 573 & 80 \\
\hline Mediomastus californiensis & 0 & 93 & 493 & 227 & 6400 \\
\hline Nephtyidae (juvenile) & 0 & 7 & 280 & 400 & 107 \\
\hline Prionospio cirrifera & 100 & 40 & 93 & 213 & 200 \\
\hline Prionospio steenstrupi & 0 & 6 & 180 & 87 & 227 \\
\hline Spiochaetopterus oculatus & 0 & 13 & 13 & 20 & 940 \\
\hline Syllis heterochaeta & 0 & 20 & 26 & 33 & 654 \\
\hline Oligochaeta & 213 & 27 & 67 & 67 & 4040 \\
\hline \multicolumn{6}{|l|}{ Mollusca } \\
\hline Mysella tumida & 0 & 7 & 27 & 13 & 360 \\
\hline Macoma balthica & 0 & 0 & 0 & 13 & 380 \\
\hline \multicolumn{6}{|l|}{ Arthropoda } \\
\hline Aoroides exilis & 160 & 807 & 993 & 167 & 60 \\
\hline Euphilomedes carcharodonta & 7 & 33 & 160 & 600 & 3660 \\
\hline Foxiphalus cognatus & 0 & 0 & 0 & 0 & 300 \\
\hline Lamprops serrata & 0 & 27 & 160 & 213 & 0 \\
\hline Munnogonium tillerae & 0 & 0 & 13 & 173 & 0 \\
\hline Nebalia pugettensis & 100 & 113 & 113 & 47 & 60 \\
\hline Photis bifurcata & 0 & 13 & 147 & 2480 & 13 \\
\hline Pinnixa schmitti & 27 & 67 & 33 & 287 & 780 \\
\hline Pleusymtes subglaber & 13 & 80 & 213 & 880 & 27 \\
\hline Synchelidium shoemakeri & 0 & 47 & 140 & 233 & 27 \\
\hline \multicolumn{6}{|l|}{ Echinodermata } \\
\hline Holothuroidea & 0 & 0 & 0 & 0 & 660 \\
\hline
\end{tabular}

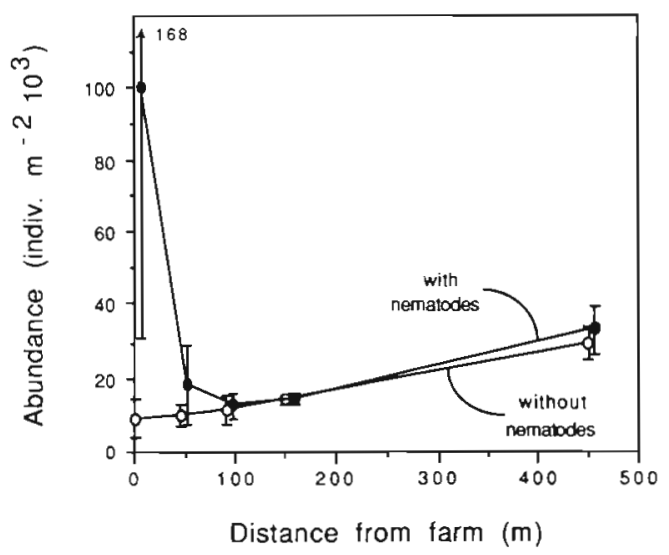

Fig. 3. Mean and standard deviation of total community abundance along the sampling transect, with ( $)$ and without

(0) the inclusion of nematodes. Values offset as in Fig. 2

quencies were expressed on the bases of both individuals and species, using proportional rather than absolute values to facilitate comparison among stations (Fig. 4). The mode of the distribution of size classes of individu- als was heavily influenced by Capitella cf. capitata at most stations and shifted from Size Class 3 (0.4 to 0.7 $\mathrm{mg})$ to Class 6 (3.2 to $6.3 \mathrm{mg}$ ) with increased proximity to the farm. Mean individual size, on the other hand, was heavily influenced by the large individuals of Size Classes 10 to 20 (0.0512 to $52.4288 \mathrm{~g}$ ), and shifted from Class 10 to Class 6 along the same gradient. Large individuals, while never abundant, were most frequently collected at those stations farthest from the farm and were absent at the most enriched stations.

The distribution of species among size classes exhibited many of the same characteristics as the distribution of individuals among size classes. Mean species size decreased with increasing proximity to the farm, but the mode of the species size distribution did not change. With increasing enrichment, many species size classes, and particularly the larger ones, disappeared and a single species size class became dominant.

The tendency for modal individual size to shift toward larger body sizes with increasing organic enrichment conflicts with the usual interpretation of 

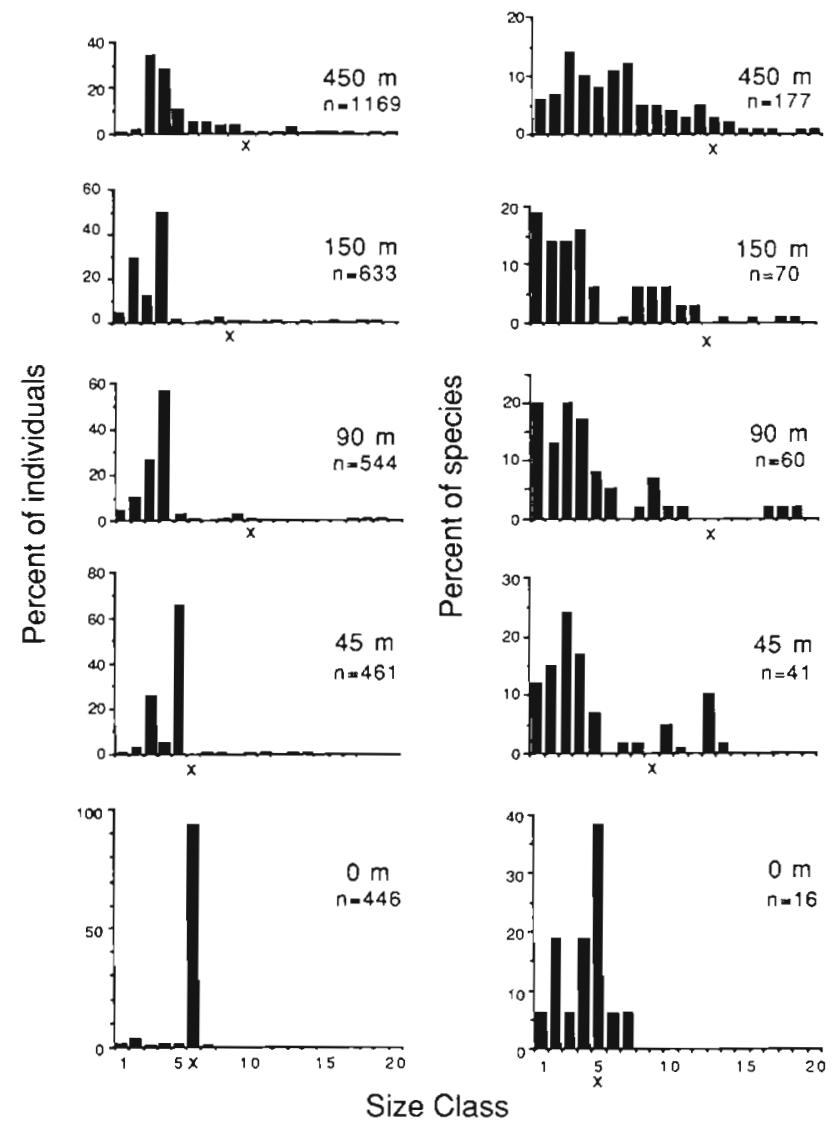

Fig. 4. Proportion of individuals and species within each geometric size class (Class $1=0.1 \mathrm{mg}$, Class $2=0.2-0.3 \mathrm{mg}$, Class $3=0.4-0.7 \mathrm{mg}$, Class $4=0.8-1.5 \mathrm{mg}, \quad$ Class $20=$ $52.4288-104.8575 \mathrm{~g})$. $\mathrm{X}$ : size class in which the mean individual size would fall

existing disturbance models. This result suggests that it is necessary to examine intra- as well as interspecific trends in body size. The hypothesis that individuals within a species may increase in size with increasing proximity to the farm was tested for 8 species that were present in abundances of $>5$ ind. sample ${ }^{-1}$ at at least 4 of the 5 transect stations. Three species (Euphilomedes carcharodonta, Aoroides exilis and Glycinde picta) showed no obvious trends in body size with distance from the farm. Larger individuals of one species (Armandia brevis) tended to be found near the farm, but the trend was not significant (Spearman rank correlation, 1-tailed test, $0.05<\mathrm{p}<0.10$ ). Body sizes of 4 species (Capitella cf. Capitata. Prionospio cirrifera, Gyptis brevipalpa and Barantolla americana) increased significantly at stations nearest the farm (Fig. 5). Thus, while interspecific measures of animal size (mean individual and mean species sizes within a sample) were directly correlated with distance from the organic source, the size of individuals within some species was inversely correlated with distance from the source.

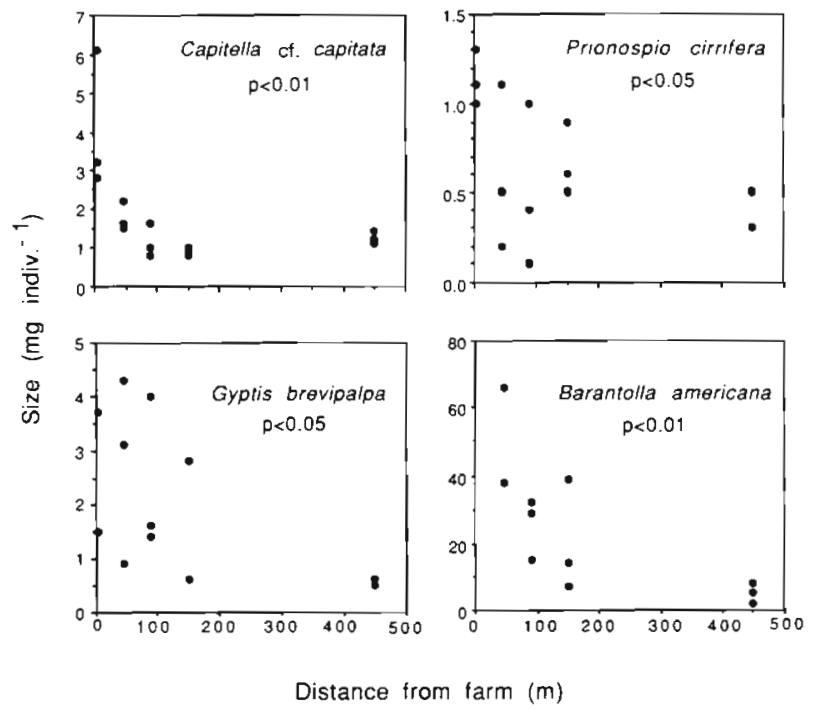

Fig. 5. Body sizes of 4 species distributed throughout the sampling transect. Mean individual body size is shown for each sample in which the species was present (maximum of 3 core samples at each of the 5 stations)

\section{Vertical distribution of animals}

Most species showed a high degree of fidelity to discrete vertical intervals in the sediment column (Fig. 6). There was little evidence of shifts in the vertical distributions of individual species along the enrichment gradient ${ }_{i}$ community-level shifts in distribution were the result of species replacement rather than intraspecific changes in vertical distribution. Crustacea, including representatives of Amphipoda, Cumacea, Isopoda, Ostracoda and Leptostraca, dominated the surface- and near-surface-dwelling species. Capitella cf. capitata was found mainly in the upper $5 \mathrm{~cm}$, with peak abundances between 1 and $2 \mathrm{~cm}$, while other capitellids were among the deepest-burrowing species collected (Mediomastus californiensis: principally 2 to $10 \mathrm{~cm}$; Notomastus tenuis: 5 to $10 \mathrm{~cm}$; and Barantolla americana: 5 to $20 \mathrm{~cm}$ ). The depth distributions are based on depths of collection and may not correspond to life positions. Animals with established burrows may retract into them when disturbed.

The vertical abundance profile of the macrofaunal community was dominated by surface and near-surface dwellers (Fig. 7). Approximately $90 \%$ of the individuals were collected at depths of $5 \mathrm{~cm}$ or less regardless of the distance from the farm site. Existing organic enrichment models suggest that the vertical extent of infaunal distribution should be restricted to shallower strata with increasing organic input. The vertical distribution of abundance at the $0 \mathrm{~m}$ station was therefore compared to the distribution at the $150 \mathrm{~m}$ station on the basis of both median depth (depth stratum containing 


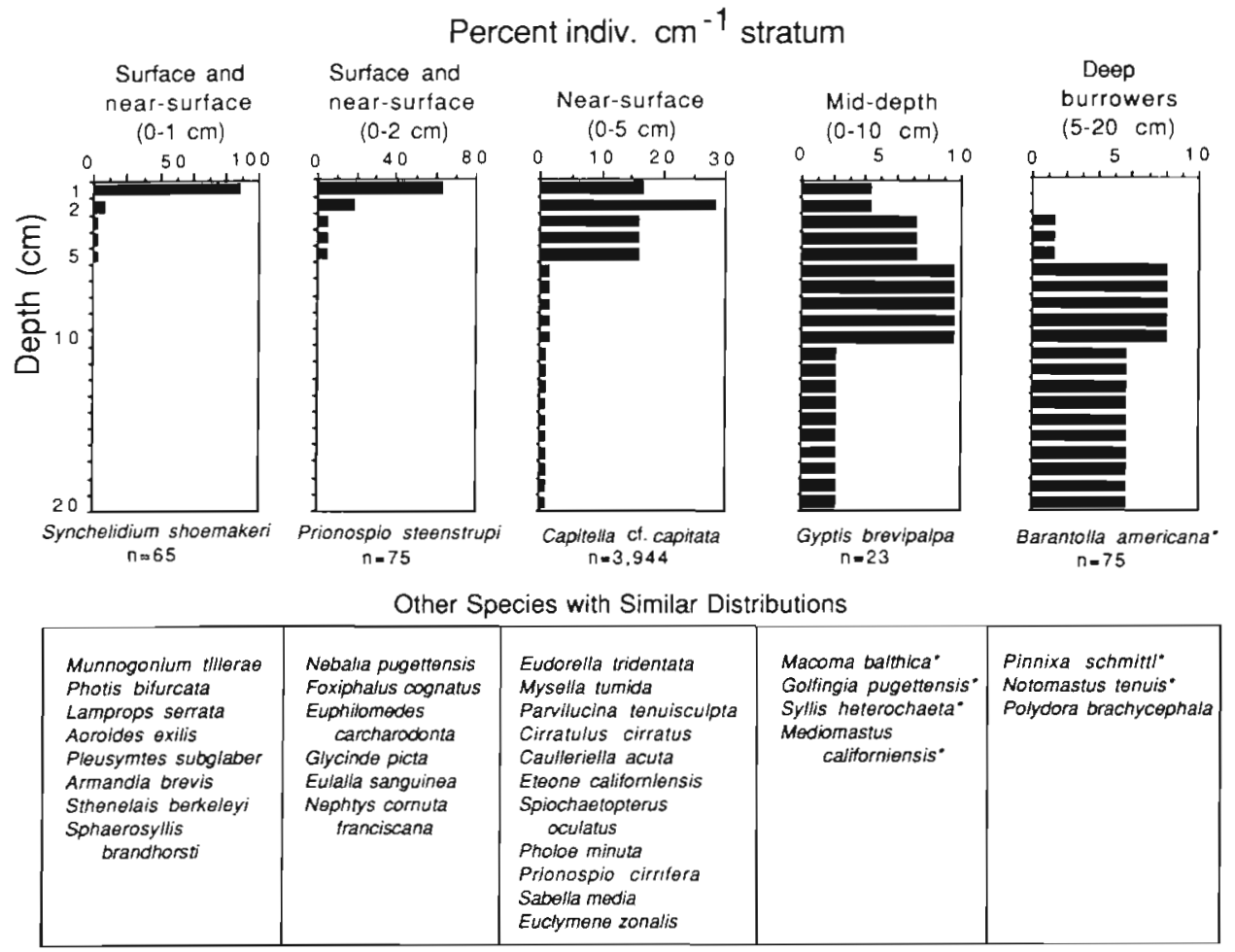

Fig. 6. Vertical distribution of selected species within the sediment column, composited over all stations. For each of 5 generalized distribution patterns, a specific example is shown and other characteristic species are listed below. Horizontal axes illustrate the individuals collected in each $\mathrm{cm}$ stratum as a percentage of total individuals collected over the full length of the cores (usually 20 $\mathrm{cm}$ ). Normalization on a $\mathrm{cm}^{-1}$ basis is necessary to compensate for the unequal thickness of the sampling intervals. For example, $48 \%$ of Capitella capitata individuals were collected in the 2 to $5 \mathrm{~cm}$ stratum, so it was arbitrarily assumed that each $1 \mathrm{~cm}$ stratum within this interval contained $16 \%$ of the total individuals. Percentage of individuals in the 10 to $20 \mathrm{~cm}$ stratum probably underestimated since the species was abundant at the $450 \mathrm{~m}$ station where sample penetration was limited to $10 \mathrm{~cm}$

\section{Percent abundance $\mathrm{cm}^{-1}$ stratum}
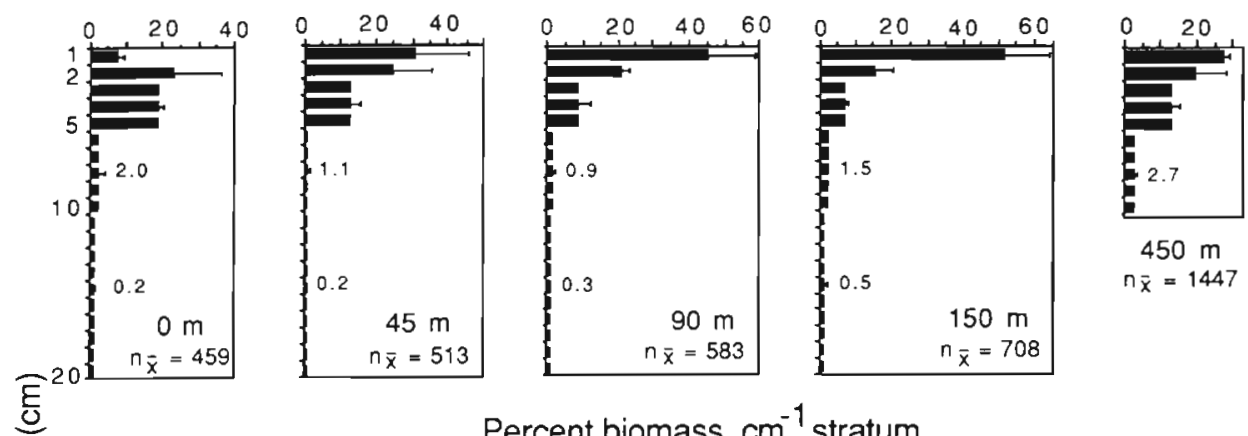

Percent biomass $\mathrm{cm}^{-1}$ stratum
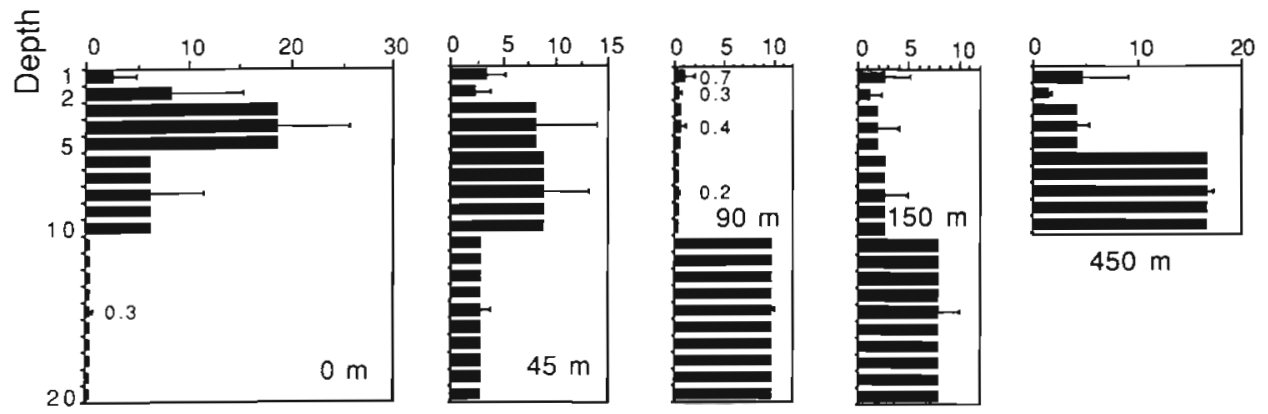

Fig. 7 Vertical distribution of total community abundance and biomass along the sampling transect. No data are available below $10 \mathrm{~cm}$ at the $450 \mathrm{~m}$ site. Mean and standard deviation are shown for each depth interval. Means are given in numerical form for some of the smaller values to enhance graphical clarity 
$50 \%$ of the cumulative distribution of individuals) and the percentage of individuals in the 10 to $20 \mathrm{~cm}$ stratum. The distributions of individuals at the 2 stations were not significantly different in the direction tested by either measure (Mann-Whitney U, 1-tailed tests, $\mathrm{p}>0.10$ ). It was not possible to use the $450 \mathrm{~m}$ station in this comparison since the cores penetrated to only $10 \mathrm{~cm}$.

A very different pattern was evident in the vertical profile of biomass. At all stations, except the $0 \mathrm{~m}$ site, most of the individuals were present above $5 \mathrm{~cm}$, but most of the biomass ( 70 to $98 \%$ ) was found below $5 \mathrm{~cm}$. The $0 \mathrm{~m}$ station had significantly less biomass at depth based on comparisons of both median depths and percentages of individuals in the 10 to $20 \mathrm{~cm}$ stratum (Mann-Whitney U, 1-tailed tests, $\mathrm{p}=0.05$ ).

With increasing distance from the farm, the contribution to total sample biomass of animals in the 10 to $20 \mathrm{~cm}$ stratum increased rapidly due to the appearance of large bivalves, including Lucinoma annulata, Macoma inquinata, $M$. nasuta and Panope generosa. At the $450 \mathrm{~m}$ site the corer was unable to penetrate below $10 \mathrm{~cm}$ because of the density of bivalve shells, but data from the 5 to $10 \mathrm{~cm}$ intervai and qualitative observations below this depth indicated that most of the biomass consisted of deep-dwelling bivalves (Mya truncata, Saxidomus giganteus), echiurans (Arhynchite pugettensis) and sipunculans (Golfingia pugettensis).

\section{Trophic structure}

Assessment of the effects of organic enrichment on trophic guilds is complicated by, among other things, the paucity of information on the autecology of many species. Since more information is available for polychaetes than for most other groups and since $75 \%$ of the macrofaunal individuals collected were polychaetes, the effects of enrichment on trophic structure were analyzed using only the polychaete data and the trophic groupings of Fauchald \& Jumars (1979).

Trophic dominance was assessed on both numerical and biomass bases including only those species accounting for more than $0.5 \%$ of the total abundance (or biomass) at each station. On both bases, trophic diversity (both richness and evenness components) was reduced with proximity to the farm (Fig. 8). All trophic groups were represented in the polychaete community at $450 \mathrm{~m}$ from the farm. Suspension feeders constituted about $10 \%$ of the community abundance and biomass at $450 \mathrm{~m}$, but disappeared entirely at a distance of 45 to $90 \mathrm{~m}$ from the farm. Surface deposit feeders aiso showed a similar decline. At the farm perimeter the community consisted largely of subsurface deposit feeders.
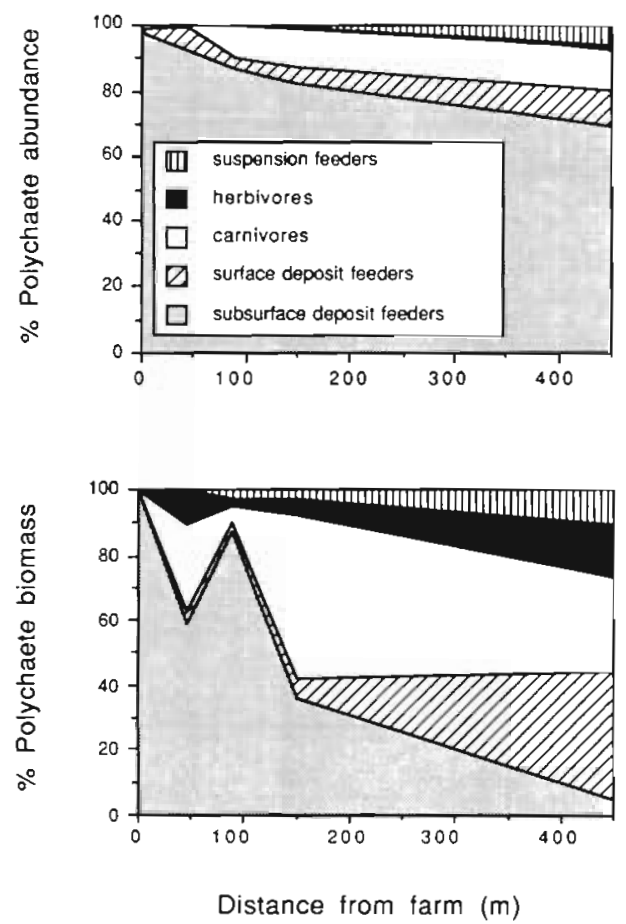

Fig. 8. Percent composition of polychaete trophic guilds along the sampling transect, calculated on both abundance and biomass bases

The principal difference between the abundanceand biomass-based trophic patterns results from differences in the relative proportions of subsurface deposit feeders. At $450 \mathrm{~m}$ this guild, represented largely by Mediomastus californiensis, Euclymene zonalis and Capitella cf. capitata, accounted for $70 \%$ of total polychaete individuals, but because of their relatively small size, their contribution to biomass was small. The larger carnivores and surface deposit feeders (e.g. Onuphis elegans, Lepidasthenia longicirrata, Neoamphitrite robusta, Thelepus setosus) accounted for most of the biomass at the $450 \mathrm{~m}$ station.

\section{Abundance-biomass comparison}

The abundance-biomass comparison ( $A B C$ ) technique has been proposed as a method for quantifying the degree of community disturbance (Warwick 1986). Species are ranked in order of dominance on the abscissa (logarithmic scale), and cumulative percentage composition is plotted on the ordinate. Two curves are generated. one based on abundance and one based on biomass. The relative positions of these 2 curves has been suggested to indicate severity of disturbance. A strong biomass dominance by a few large, rare species is predicted in undisturbed environments, and the biomass curve should overlie the abundance curve for its 
entire length. Under grossly disturbed conditions, the community becomes numerically dominated by a few opportunistic species having small body sizes, and the abundance curve should overlie the biomass curve. Under moderate disturbance, the 2 curves will tend to be superimposed, often crossing one another.

$A B C$ curves at the 5 stations along the transect are shown in Fig. 9. At the $0 \mathrm{~m}$ station the biomass curve overlays the abundance curve - a result that would be interpreted in the context of the $\mathrm{ABC}$ model as indicating an undisturbed community. The intercept of both curves, however, is over $90 \%$ due to the dominance of Capitella cf. capitata $194 \%$ of the individuals and $98 \%$ of the biomass). Using ABC criteria, the 45, 90 and $150 \mathrm{~m}$ stations would be characterized as grossly disturbed, moderately disturbed, and undisturbed, respectively. The $450 \mathrm{~m}$ station would be considered moderately disturbed by $\mathrm{ABC}$ criteria. Assignment to a category is in part subjective, but I have tried to be consistent with the numerous examples provided in Warwick et al. (1987).

\section{DISCUSSION}

Alterations of sediment chemistry as a result of organic enrichment were evident only to a distance of $45 \mathrm{~m}$ from the farm, but benthic community effects were apparent to a distance of at least $150 \mathrm{~m}$. These observations suggest that the fauna are sensitive to enrichment at levels not detectable with the gross chemical measures used or that faunal patterns reflect integration of enrichment effects more severe than those described by the one sampling 'snapshot'. Most biological indices used in this study illustrated gradual and monotonic faunal changes from the assemblage at the $450 \mathrm{~m}$ station to an assemblage at the $0 \mathrm{~m}$ station representative of highly enriched conditions. With increasing proximity to the farm there was: (1) reduced areal species richness; (2) reduced macrofaunal biomass; (3) an order-of-magnitude increase in Capitella cf. capitata density; and (4) a slight decrease in total macrofaunal abundance. On the basis of total macrofaunal abundance there was no evidence of the peak of opportunists' (Pearson \& Rosenberg 1978) often reported in enriched areas, including near fish farms (Brown et al. 1987). It is possible that such a peak existed at some point between the sampling stations or under the farm where sampling was not feasible.

The abundance-biomass comparison technique yielded results inconsistent with many of the other biological indices. Initial tests of the $\mathrm{ABC}$ technique by its developer and co-workers suggested it could be used to identify areas disturbed by organic enrichment as well as in a wide range of disturbance and succes-
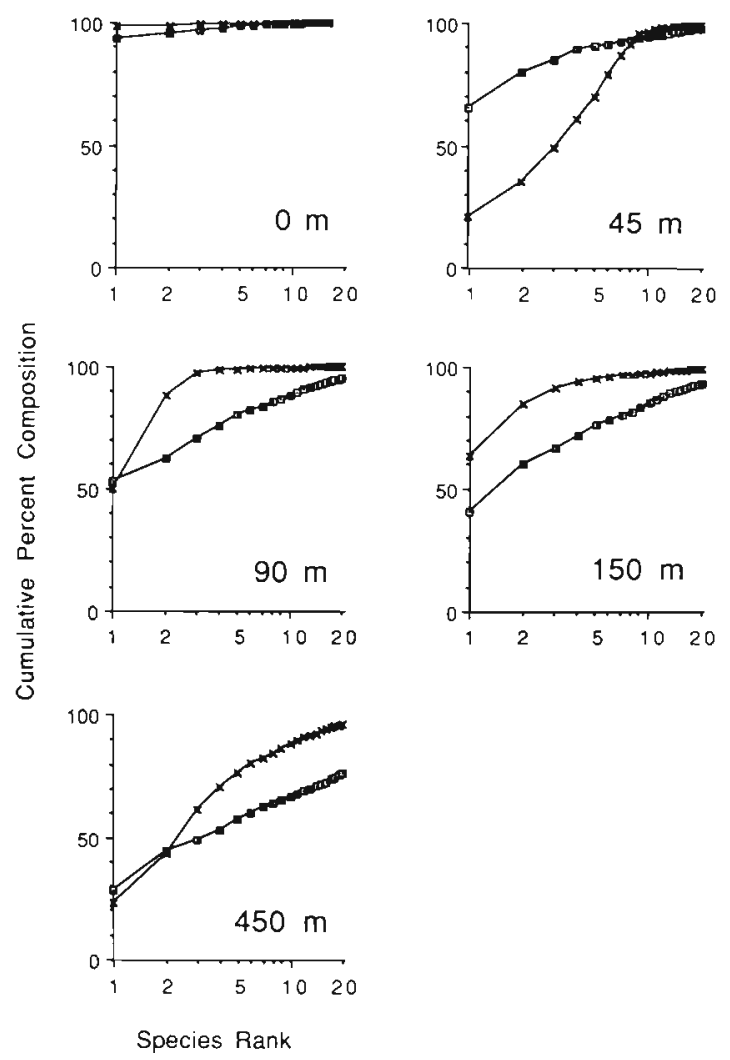

Fig. 9. Abundance-biomass comparison curves at all sampling sites. $(x)$ biomass; $(\cdot)$ abundance

sional scenarios (Warwick 1986, Warwick \& Ruswahyuni 1987, Warwick et al. 1987, Gray et al. 1988, Austen et al. 1989). The technique was also judged successful in a test near a fish culture site (Ritz et al. 1989), although the limited data provided in the paper make it difficult to verify that conclusion. In other tests (Beukema 1988, Ibanez \& Dauvin 1988) the ABC technique incorrectly characterized the disturbance status at some sites, and the same appears to be the case in this investigation. The station at the farm perimeter would be characterized as undisturbed by strict application of $\mathrm{ABC}$ criteria, but the numerical dominance of a single species (Capitella cf. capitata) clearly indicates the area to be typical of gross enrichment. Based on $\mathrm{ABC}$ the 150 and $450 \mathrm{~m}$ stations would be characterized as undisturbed and moderately disturbed, respectively. One or both of these stations have been misclassified by the technique, or a confounding and unidentified faunal gradient exists. It seems unlikely that the $4.50 \mathrm{~m}$ station has been affected by culture activities. The most abundant species, Mediomastus californiensis, is often numerically dominant in shallow, fine sand areas of Puget Sound with low organic carbon content (P. Striplin unpubl.). Most of the dominant species at the $450 \mathrm{~m}$ site (e.g. 
Euphilomedes carcharodonta, Pinnixa schmitti, Euclymene zonalis, Mysella tumida), and the species composition in general, are very similar in nearby sandy, subtidal areas of Puget Sound unaffected by anthropogenic organic input (Lie 1968, Nichols 1968, Lie \& Evans 1973).

The gradients in species richness, abundance and biomass observed in the vicinity of the farm are typical of organic enrichment in general, but more insight into enrichment effects on the macrobenthos is gained by analysis of changes in animal size, vertical distribution and trophic patterns. Organically enriched areas are generally thought to be characterized by macrofauna with relatively small body sizes. This study has demonstrated that some interspecific measures of animal size (both mean individual and mean species size) were negatively correlated with increasing organic enrichment as expected. Intraspecific measures of animal size, however, were positively correlated with increasing organic enrichment.

The relationship between small body size and organic enrichment proposed by Pearson \& Rosenberg (1978) was based on mean individual size (total sample biomass divided by total sample abundance: T. Pearson pers. comm.). Warwick et al. (1986) assumed that the same relationship applies to mean species size and that, with increasing organic enrichment, large taxa are replaced by smaller taxa. Both trends were observed in this study, but size frequency data reveal potential problems with interpretations of patterns in mean individual or mean species size. Both parameters increase with distance from the source of organic input, but this response is entirely attributable to the presence of a few very large species represented by a few individuals at the least affected stations. Measures of central tendency less affected by the highly skewed distribution of animal sizes (e.g. geometric mean, median, mode) may frequently fail to show the trends exhibited by the mean. Mean individual size may provide one means of identifying disturbed areas (Pearson 1987), but it should be recognized that only a very few individuals are driving changes in the index. The parameter, therefore, is sensitive to all the methodological problems inherent in sampling rare species such as a high degree of among-sample variability with extensive replication required.

The mechanisms by which organic enrichment may selectively eliminate the larger species are not clear. Body size is the sum of a host of environmental and evolutionary pressures. Species found in enriched environments tend to be opportunistic; that is, they are colonizers of habitats that are patchy both temporally and spatially. Small body size may be a consequence of selective pressures for morphological simplicity and rapid maturation in such species, or it may reflect feeding and digestive constraints (MacArthur \& Wilson 1967, Grassle \& Grassle 1974, Penry \& Jumars 1987, in press).

Small animals, with their relatively large surface area to volume ratio, may be better able to survive reduced availability of dissolved oxygen in pore waters of enriched sediments. The fact, however, that individuals within some species tended to be larger at the most enriched sites suggests that, for these species at least, surface area constraints on oxygen uptake are not the primary determinant of body size.

Intraspecific changes in body size with organic enrichment have been largely unexplored. Individuals of species that showed consistent trends in body size with distance from the farm were larger at the most enriched sites. For those species with physiological, behavioral or life history adaptations that enable them to exploit enriched areas, increased organic input presumably increases food quantity and/or quality, and thus individuals may be able to grow larger. In manipulative field experiments, Capitella capitata provided with sewage sludge grew larger (Young \& Young 1978). Of 9 polychaete species examined in Tampa Bay, Florida, 4, including C. capitata, were significantly larger in the populations nearest a sewage outfall; individuals of only one species were significantly smaller at the outfall site (Dauer \& Conner 1980). At another site, however, sewage disposal was related to smaller C. capitata body size (Dauer \& Conner 1980), indicating the relationship between enrichment and body size is complex and may be complicated by sibling species within the C. capitata complex (Grassle \& Grassle 1976 ) or by co-occurring toxicants.

In this study, as in many previous studies (Myers 1977, Spies \& Davis 1979, Rhoads et al. 1985, Schaffner et al. 1987) ca $90 \%$ of the macrofauna individuals were found in the 0 to $5 \mathrm{~cm}$ stratum. Sampling only the upper $5 \mathrm{~cm}$ of the sediment column, however, misses many large, deep-burrowing species that are few in number, but account for most of the total biomass. In this study, 40 to $90 \%$ of the biomass in the upper 0 to $20 \mathrm{~cm}$ would have been missed by sampling to a depth of only $5 \mathrm{~cm}$.

The effect of organic enrichment on vertical distribution was only observed in biomass profiles - vertical distributions of infaunal biomass changed dramatically with distance from the source of organic input. Most individuals typically are present at or near the sediment surface regardless of the degree of enrichment, so shifts in the vertical abundance profile are an insensitive measure of organic enrichment. Areas with less organic input are characterized by a few individuals of large, deep-burrowing species. Their presence or absence thus has little effect on the total community abundance profile and is only reflected in the biomass profile. 
Since organic enrichment alters the types and amounts of food resources available to the macrobenthos, it seems intuitively attractive to quantify enrichment effects by shifts in the proportions of various trophic guilds. The increased numerical dominance of subsurface deposit feeders with organic enrichment observed in this study was reported by Pearson \& Rosenberg (1978), but, in both cases, trends in dominance of the various trophic guilds largely reflected trends in the dominance of Capitella cf. capitata. The analysis thus provided little information on broader functional changes in the community and, in this case, was largely a trivial exercise.

The difficulties of assigning species to particular trophic classes include: (1) the frequent absence of species-specific information on feeding strategies and the potential for error in family-level generalizations; (2) inconsistencies in the literature on feeding modes due to methodological differences or inter-population variability; (3) the difficulty in applying trophic schemes developed for one major taxon to other taxa which may utilize different food resources; (4) behavioral modification in feeding mode depending upon environmental conditions (Fauchald \& Jumars 1979, Maurer et al. 1979, Dauer et al. 1981). In this study the abundance or biomass contribution of a species potentially utilizing any of several feeding strategies was equally divided among the potential trophic categories - a necessary but ecologically unsatisfying procedure.

Not surprisingly, attempts to utilize trophic classifications in analysis of environmental gradients have produced mixed results. Feeding guild dominance may correlate with environmental variables in some instances (Gaston 1987), but in other cases the correlations may be no better than those of random species groupings (Dauer 1984). Contrary to predictions of existing organic enrichment models, there appears to be no feeding strategy characteristic of species typical of enriched environments. Capitella cf. capitata is a shallow subsurface deposit feeder. Spionids typical of enriched habitats (Scolelepis, Streblospio and Polydora) function as both suspension and surface deposit feeders. Dorvilleids associated with enriched conditions (Protodorvillea, Schistomeringos and Ophryotrocha) may, depending on the species, be carnivores, herbivores or omnivores. The fact that no trophic groups are clearly characteristic of organic-rich habitats may merely reflect inadequate natural history information, but more probably reflects difficulties in using trophic patterns as a measure of enrichmentinduced disturbance.

Much current thinking on the benthic effects of organic enrichment has been shaped by qualitative, empirical models. Some of the concepts of these models have become entrenched in disturbance theory, although traditional benthic sampling methodology has been inadequate to provide quantitative verification. This study provided this quantitative analysis and indicates some conceptual revisions may be necessary. Further work on the effects of organic enrichment on animal size and vertical distribution are necessary to establish if the trends noted in this study can be generalized to other sites. Research should be directed towards a greater understanding of the processes underlying these faunal patterns, and how accompanying functional changes could alter, for example, rates of nutrient regeneration and bioturbation.

Acknowledgements. I thank T. Pearson for discussions on organic enrichment and D. Henry, P. Jumars, D. Penry, and 3 anonymous reviewers for comments on the manuscript. M. Johnston and J. Cummins made available the facilities of the EPA Region 10 Laboratory. This work was supported by the U.S. Environmental Protection Agency, Region 10 through Cooperative Agreement CX-813705-01 with the Puget Sound Institute, University of Washington. Contribution no. 1841 from the School of Oceanography, University of Washington.

\section{LITERATURE CITED}

Austen, M. C., Warwick, R. M., Rosado, M. C. (1989). Meiobenthic and macrobenthic community structure along a putative pollution gradient in southern Portugal. Mar. Pollut. Bull. 20: 398-405

Beukema, J. J. (1988). An evaluation of the ABC-method (abundance/biomass comparison) as applied to macrozoobenthic communities living on tidal flats in the Dutch Wadden Sea. Mar. Biol. 99: 425-433

Brown, J. R., Gowen, R. J., McLusky, D. S. (1987). The effect of salmon farming on the benthos of a Scottish sea loch. J. exp. Mar. Biol. Ecol. 109: 39-51

Dauer, D. M. (1984). The use of polychaete feeding guilds as biological variables. Mar. Pollut. Bull. 15: 301-305

Dauer, D. M., Conner, W G. (1980). Effects of moderate sewage input on benthic polychaete populations. Estuar. coast. Mar. Sci, 10: 335-346

Dauer, D. M., Maybury, C. A., Ewing, R. M. (1981). Feeding behavior and general ecology of several spionid polychaetes from the Chesapeake Bay. J. exp. mar. Biol. Ecol. 54: 21-38

Fauchald, K., Jumars, P. A. (1979). The diet of worms: a study of polychaete feeding guilds. Oceanogr. mar. Biol. A. Rev. 17: $193-284$

Gaston, G. R. (1987). Benthic Polychaeta of the Middle Atlantic Bight: feeding and distribution. Mar. Ecol. Prog. Ser. 36: 251-262

Gowen, R. J., Bradbury, N. B. (1987). The ecological impact of salmonid farming in coastal waters: a review. Oceanogr. mar. Biol. A. Rev. 25: 563-575

Grassle, J. F., Grassle, J. P. (1974). Opportunistic life histories and genetic systems in marine benthic polychaetes. J. mar. Res. 32: 253-284

Grassle, J. P., Grassle, J. F. (1976). Sibling species in the marine pollution indicator Capitella (Polychaeta). Science 192: $567-569$

Gray, J. S. (1979). Pollution-induced changes in populations. Phil. Trans. R. Soc. (Ser. B) 286: 545-561 
Gray, J S., Aschan, M., Carr, M. R., Clarke, K. R., Green, R. H., Pearson, T H., Rosenberg, R., Warwick, R. M. (1988). Analysis of community attributes of the benthic macrofauna of Frierfjord/Langesundfjord and in a mesocosm experiment. Mar. Ecol. Prog. Ser. 46: 151-165

Green, E. J., Schnitker, D. (1974). The direct titration of watersoluble sulfide in estuarine muds of Montsweag Bay. Maine. Mar. Chem. 2: 111-124

Hedges, J. I., Stern, J. H. (1984). Carbon and nitrogen determinations of carbonate-containing solids. Limnol. Oceanogr. 29: $657-663$.

Ibanez, F., Dauvin, J.-C. (1988). Long-term changes (1977-1987) in a muddy fine sand Abra alba-Melinna palmata community from the Western English Channel: multivariate time-series analysis. Mar. Ecol. Prog. Ser. 49: $65-81$

Lie, U. (1968). A quantitative study of benthic infauna in Puget Sound, Washington, U.S.A., in 1963-1964. FiskDir. Skr. (Ser. Havunders.) 14: 229-556

Lie, U., Evans, R. (1973). Long-term variability in the structure of subtidal benthic communities in Puget Sound, Washington, U.S.A. Mar. Biol. 21: 122-126

MacArthur, R. H., Wilson, E. O. (1967). The theory of island biogeography. Princeton Univ. Press, Princeton

Maurer, D., Watling, L., Leathem, W., Kinner, P. (1979). Seasonal changes in feeding types of estuarine benthic invertebrates from Delaware Bay, J. exp. mar. Biol. Ecol. 36: $125-155$

Myers, A. C. (1977). Sediment processing in a marine subtidal sandy bottom community: II. Biological consequences. J. mar. Res. 35: 633-647

Nichols, F. H. (1968). A quantitative study of benthic polychaete assemblages in Port Madison, Washington. M.S. thesis, University of Washington, Seattle

Pearson, T. H. (1987). Benthic ecology in an accumulating sludge-disposal site. In: Capuzzo, J., Kester, D. R. (eds.) Biological processes and waste in the ocean, Vol. I, Oceanic processes in marine pollution. Robert E. Krieger Publishing Co., Malabar, Florida, p. 195-200

Pearson, T. H., Rosenberg, R. (1978). Macrobenthic succession in relation to organic enrichment and pollution of the marine environment. Oceanogr. mar. Biol. A. Rev. 16: 229-311

Pearson, T H., Stanley, S. O. (1979). Comparative measurements of the redox potentials of marine sediments as a rapid means of assessing the effect of organic pollution. Mar. Biol. 53: 371-379

Penry, D. P., Jumars, P. A. (1987). Modeling animal guts as chemical reactors. Am. Nat. 129: 69-96

This article was submitted to the editor
Penry, D. P., Jumars, P. A. (in press). Gut architecture, digestive constraints and feeding ecology of deposit-feeding and carnivorous polychaetes. Oecologia (Berl.)

Rhoads, D. C., Boesch, D. F., Zhican, T., Fengshan, X. Liqiang, H., Nilsen, K. J. (1985). Macrobenthos and sedimentary facies on the Changjiang delta platform and adjacent continental shelf, East China Sea. Cont. Shelf Res. 4: 189-213

Rhoads, D. C., Boyer, L. F. (1982). The effects of marine benthos on physical properties of sediments: a successional perspective. In: McCall, P. L., Tevesz, M. (eds.) Animal-sediment relations. Plenum Press, New York. p. 3-52

Ritz, D. A., Lewis, M. E., Shen, M. (1989). Response to organic enrichment of infaunal macrobenthic communities under salmonid seacages. Mar. Biol. 103: 211-214

Schaffner, L. C., Diaz, R. J., Olsen, C. R., Larsen, I. L. (1987) Faunal characteristics and sediment accumulation processes in the James River Estuary, Virginia. Estuar. coast Shelf Sci. 25: 211-226

Simon, J. L., Dauer, D. M. (1977). Reestablishment of a benthic community following natural defaunation. In: Coull, B. C. (ed.) Ecology of marine benthos. Univ. of South Carolina Press, Columbia. p. 139-154

Spies, R. B., Davis, P. H. (1979\}. The infaunal benthos of a natural oil seep in the Santa Barbara Channel. Mar. Biol. 50: $227-237$

Thiel, H. (1978). Benthos in upwelling regions. In: Boje, R., Tomczak, M. (eds.) Upwelling ecosystems. Springer-Verlag, Berlin, p. 124-138

Warwick, R. M. (1984). Species size distributions in marine benthic communities. Oecologia (Berl.) 61. 32-41

Warwick, R. M. (1986). A new method for detecting pollution effects on marine macrobenthic communities. Mar. Biol 92: $557-562$

Warwick, R. M., Collins, N. R., Gee, J. M., George, C. L. (1986). Species size distributions of benthic and pelagic Metazoa: evidence for interaction. Mar. Ecol. Prog. Ser. 34: 63-68

Warwick, R. M., Pearson, T. H., Ruswahyuni (1987). Detection of pollution effects on marine macrobenthos: further evaluation of the species abundance/biomass method. Mar. Biol. 95: $193-200$

Warwick, R. M., Ruswahyuni (1987). Comparative study of the structure of some tropical and temperate marine soft-bottom macrobenthic communities. Mar. Biol. 95: 641-649

Young, D. K., Young, M. K. (1978) Regulation of species densities of seagrass-associated macrobenthos: evidence from field experiments in the Indian River estuary, Florida. J. mar. Res. 36: 569-593

Manuscript first received: September 26, 1989

Revised version accepted: January 11, 1990 